Journal of Applied Pharmaceutical Science Vol. 5 (10), pp. 067-072, October, 2015

Available online at http://www.japsonline.com

DOI: $10.7324 / \mathrm{JAPS} .2015 .501012$

ISSN 2231-3354 (cc) BY-NC-SA

\title{
Evaluation of fungistatic potential of lichen extracts against Fusarium solani (Mart.) Sacc. causing Rhizome rot disease in Ginger
}

\author{
Rashmi Shivanna, Rajkumar H Garampalli* \\ Department of studies in Botany, Manasagangotri, University of Mysore, Mysore, Karnataka, India.
}

\author{
ARTICLE INFO \\ Article history: \\ Received on: 05/07/2015 \\ Revised on: 22/07/2015 \\ Accepted on: 07/08/2015 \\ Available online: 28/10/2015 \\ Key words: \\ Lichens, Parmotrema \\ tinctorum, Flavoparmelia \\ caperata, Fusarium solani.
}

\begin{abstract}
Eight lichens were collected, identified and solvent extract were obtained using methanol and ethyl acetate in soxhlet apparatus. Antifungal properties of lichens were determined by Agar well diffusion method, Microdilution assay and TLC- Bioautographic technique. The largest zone of inhibition in well diffusion method was recorded (in $\mathrm{mm}$ ) with the ethyl acetate extract of Parmotrema tinctorum with $18.6 \pm 1.15$ followed by Teloschistes flavicans with $18.6 \pm 0.5$. The maximum antifungal activity was found in the extracts of lichen Parmotrema tinctorum and Flavoparmelia caperata with low MIC value of $1.562 \mathrm{mg} / \mathrm{ml}$. Flavoparmelia caperata extract was active with a clear zone on TLC bioautogram of the tested organism indicating two zones of growth inhibition at an $\mathrm{Rf}$ value of $0.46,0.6$. Comparatively ethyl acetate extract showed a strong antifungal activity than methanolic extract. The results were promising with potential drug candidate having a fungitoxic effect to reinforce bioprospecting of lichens as a bio-fungicide.
\end{abstract}

\section{INTRODUCTION}

Lichen is a stable, ecologically obligate, self-supporting mutualism between an exhabitant fungus (the mycobiont) and one or more inhabitant, extracellulary located unicellular or filamentous photoautotrophic partners (the photobiont: alga or cyanobacterium) (Molnár and Farkas, 2010).Lichens are valuable plantresources and are used as medicine, food, fodder, perfume, spice, dyes and for miscellaneous purposes throughout the world. Lichens are inherently resistant to microbial infection due to the production of large numbers of unique secondary metabolites (Huneck, 1999). These lichens produce a diverse range of primary and secondary metabolites (Hale, 1983). Slow growth and often harsh living conditions, make the production of protective metabolites a necessity to lichens, and many secondary constituents are believed to serve as antigrowth, antimicrobial or antiherbivore agents (Rankovic et al., 2008). The lichen secondary metabolites show a wide range of potentially useful biological activities like antimycobacterial, antiviral, antiinflammatory, analgesic, antipyretic, antiproliferative and cytotoxic properties (Boustie and Grube, 2005).Lichens and their secondary metabolites have shown great potential as antifungal

\footnotetext{
* Corresponding Author

Email: dr.hgrajkumar@botany.uni-mysore.ac.in
}

source (Muller, 2002). But as far as plant diseases are concerned the lichens are very less explored and, especially, against fungal plant pathogens there is very little information reported till yet (Goel et al., 2004; Halama and Haluwin, 2004;Babiah et al., 2014a;Vivek et al., 2014; Kekuda et al., 2014). Plant diseases may result in less food or of food in poor quality or may sometimes be poisonous and unfit for consumption. Some plant diseases may wipe out entire plant species. Ginger (Zingiber officinale Rosc.) is an important commercial crop cultivated throughout India for its rhizome as a spice. India is the largest producer of ginger accounting for about $1 / 3^{\text {rd }}$ of total world output. It is an important crop that earns a sizeable amount of foreign exchange for the country (Tarafdar and Saha 2007). It has high medicinal value, hence it is used in traditional Ayurvedic medicine. It was classified as a stimulant and carminative and used frequently for dyspepsia, gastroparesis, slow motility symptoms, constipation and colic. Ginger is affected by several fungal pathogens (Dohroo, 1993). Among which, rhizome rot caused by Fusarium solani is most common (Kumar, 1977). Crop loss due to rot-causing fungal pathogens is a significant problem. Controlling plant disease may result in better more food of better quality (Agrios, 2005). Since a decade people are using pesticides of toxic chemicals and even synthetic fungicides to control pathogens. The control of these fungi by synthetic fungicides is clouded by lots of drawbacks such as severe human and environmental toxicity effects and high costs. 
Their high costs make them less accessible particularly by rural farmers. These setbacks warrant an alternative source of fungicide. The aim of the present investigation is to evaluate the fungitoxic effect of lichens in the management of rhizome rot of ginger caused by Fusarium solani (Mart.) Sacc.

\section{MATERIALS AND METHODS}

\section{Collection and identification of lichen material}

The lichens were collected from in and around Madikeri and Chamarajanagar districts in Karnataka state, India. Identification of lichens were done based on morphology and biochemical tests, e.g., (1) growth form: Foliose or fruticose length of thallus; (2) color and texture of thallus; (3) presence or absence of reproductible structures (isidia, soredia, apothecium or perithecium); (4) thalline spot test (K, C, KC, P- test); (5) Thin layer chromatography (TLC). For the thalline spot test, the upper cortex of each specimen was initially scraped off with a razor blade to expose the medulla. Then, different chemical reagents, e.g., potassium hydroxide $(\mathrm{K})$ and Calcium hypochlorite $(\mathrm{C})$, pphenylenediamine (P)were spotted directly onto the exposed medulla. Any immediate change in color of the thallus indicates a positive reaction (Awathi 1988, 2000; Goward et al. 1994; Malcolm and Galloway 1997).

\section{Solvent Extraction}

Collected samples were washed thoroughly with distilled water and shade dried at room temperature. The dried lichens were milled to a fine power with the help of a blender. Powdered lichen samples of about 10 gms from each species were extracted by standard Soxhlet extraction procedure using Ethyl acetate and Methanol solvents. The lichen extracts were filtered through sterile Whatman No. 1 filter paper and concentrated in vacuum under reduced pressure and the weight/yield of the crude extracts were determined and preserved at $5{ }^{\circ} \mathrm{C}$ in airtight bottles until further use.

\section{Fungal Test Organism}

The fungus Fusarium solani, a causal organism of Rhizome rot in ginger was isolated from the diseased rhizome part of ginger by standard blotter method and the fungi were identified on the basis of their typical structure and basic characters (Domsch and Gams, 1972). The isolated fungus from the diseased ginger samples was maintained on potato dextrose agar (Himedia) at 26$28^{\circ} \mathrm{C}$. The standard culture inoculum was prepared on Potato Dextrose Broth by adjusting the spore range of $1 \times 10^{6}-5 \times 10^{6}$ spores /ml (Aberkene et al., 2002).

\section{Antifungal Activity Assay \\ Agar well diffusion assay}

$100 \mu \mathrm{l}$ of fungal suspension was spread on the solidified Potato dextrose agar medium and wells were punched using $5 \mathrm{~mm}$ cork borer, a concentration of $30 \mathrm{mg} / \mathrm{ml}$ extracts of $100 \mu \mathrm{l}$ was loaded into the wells and the solvents of the same were used as a negative control. The plates were kept for incubation for 4-7 days; the diameter of the zone of inhibition of the tested microorganism by the given extract was measured in millimeters. All experiments were performed in triplicate. To every sample tested, a set of positive control (Bavistin) and negative control (respective solvents) was run parallel.

\section{Microdilution assay}

Determination of Minimum inhibitory concentration [MIC] was carried out by microdilution method. The MIC is to determine the lowest concentration of an antifungal agent that appears to inhibit growth of the fungus (Andrews, 2011). MICs were calculated for the extract that had antifungal activity. Residues of different extracts were dissolved in respected solvents to a concentration of $50 \mathrm{mg} / \mathrm{ml}$. The plant extracts $(100 \mu \mathrm{l})$ were serially diluted $50 \%$ with solvents in 96 well flat bottomed microtitre plates. Fungal cultures were transferred into fresh Potato dextrose broth, and $100 \mu \mathrm{l}$ of this was added to each well, $40 \mu \mathrm{l}$ of 2, 3, 5- triphenyltetrazolium chloride [TTC] dissolved in water was added to each of the micro plate wells, as growth indicator. Appropriate solvent blanks as control were included. The micro plates were covered with a cling film and incubated for 2-3 days at $26^{\circ} \mathrm{C}$ and at $100 \%$ relative humidity (Eloff, 1998). The MIC was recorded by visual analysis in microtitre plate wells, where the lowest concentration of the lichen extract that inhibited fungal growth after 48 to 72 hours of incubation will not change its colour to formazen dye.

\section{TLC-Bioautography method}

Bioautographic method was developed to determine active compounds. Aluminium-backed TLC plates (Aluchrosep Silica Gel $60 / \mathrm{UV}_{254}$ for TLC) were loaded with $20 \mu \mathrm{l}$ of $100 \mu \mathrm{g}$ extracts. The TLC plate was developed in solvent system A (180

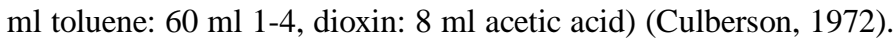
The chromatogram was dried for complete removal of solvents. Fungal inoculum solution was prepared containing approximately 3 x $10^{4}$ spores $/ \mathrm{ml}$ of actively growing fungi. Developed chromatogram was placed in petridish molten potato dextrose agar seeded with fungal inoculum was poured on the chromatogram. After agar got solidified the petri plates were kept at $4^{\circ} \mathrm{C}$ for diffusion for 3 hours and plates were incubated at room temperature for 4 days. Fungal growth inhibition appeared as clear zones against a dark background. The $\mathrm{R}_{\mathrm{f}}$ value of the zone of inhibition is recorded.

\section{RESULTS}

A total of eight lichens were identified in which, six lichens were of foliose growth form and two lichens were of fruticose growth form. Five species Flavoparmelia caperata (L.) Ach., Parmotrema austrosinensis (Zahlbr.) Hale, Parmotrema grayanum (Hue) Hale, Parmotrema reticulatum (Taylor) Choisy and Parmotrema tinctorum Nyl. belongs to family Parmeliaceae, Physcia aipolia (Ehrh. ex Humb.) Furnr. belongs to family 
Physciaceae, Roccella montagnei Bèl. Emend. Awas. belongs to family Roccellaceae and Teloschistes flavicans (Swartz) Norm. Belongs to family Teloschistaceae (Table 1).

Extraction of lichens with Ethyl acetate and methanol extracts yielded a mass from 332 to $1330 \mathrm{mg} / \mathrm{ml}$. Well diffusion assay was carried out to test the inhibition of lichens against the fungi. The zones of inhibition for both extracts ranged from $12.3 \pm 0.5$ to $18.6 \pm 1.15 \mathrm{~mm}$ to inhibit the phytopathogenic fungi Fusarium solani (Mart.) Sacc., a causal organism of rhizome rot of Ginger. Comparatively ethyl acetate extract showed a strong antifungal activity than methanolic extract. The largest zone of inhibition was recorded with the ethyl acetate extract of Parmotrema tinctorum with $18.6 \pm 1.15 \mathrm{~mm}$ followed by Teloschistes flavicans with $18.6 \pm 0.5 \mathrm{~mm}$. Methanol extract showed activity in only two lichens Flavoparmelia caperata and Roccella montagne $i$ with $12.6 \pm 0.5$ and $11.6 \pm 0.5 \mathrm{~mm}$ respectively (Table.2). The MIC was carried out in 96 well flat bottom microtitre plates to record the minimum inhibition concentration of extract at which the activity of the pathogen will be inhibited. The lower the MIC value, the more active is the extract at a particular concentration. The MIC of both the extracts related to the tested fungi were $1.562-12.25 \mathrm{mg} / \mathrm{ml}$. The maximum antifungal activity was found in the extracts of lichen Parmotrema tinctorum and
Flavoparmelia caperata with low MIC value of $1.562 \mathrm{mg} / \mathrm{ml}$. There was no inhibition of growth in wells of methanol and ethyl acetate used as our solvent blank, which means these solvents did not have effect on the tested organism, proving it good solvent system for bioassays. Bioautography was carried out to test the zone of inhibition on TLC plates. Flavoparmelia caperata extract was active with a clear zone on TLC bioautogram of the tested organism indicating lack of spore germination of the pathogenat an $\mathrm{R}_{\mathrm{f}} \mathrm{value}$ of 0.46 , 0.6 (Fig 1). Parmotrema tinctorum at 0.67 , Teloschistes flavicans at 0.61, Parmotrema grayanum at 0.64 and Physcia aipolia at $\mathrm{R}_{\mathrm{f}}$ 0.77. Parmotrema austrosinensis, Parmotrema reticulatum and Roccella montagnei did not show inhibition zone on bioautogram. Total activity of a plant is the quantity of material extracted from $10 \mathrm{gms}$ of dried plant material divided by the MIC value obtained (Mdee et al., 2009). It indicates the largest volume to which the biologically active compounds in $10 \mathrm{gm}$ of plant material can be diluted and still inhibits the growth of the test organism. Since Parmotrema tinctorum and Flavoparmelia caperata showed least MIC value, total activity of these is $414.85 \mathrm{ml}$ and $851.47 \mathrm{ml}$ respectively (Table 3). Which means 10 gms of lichen extracts can be mixed with $414.85 \mathrm{ml}$ and $851.47 \mathrm{ml}$ of ethyl acetate and still inhibits the pathogen Fusarium solani which causes rhizome rot in ginger.
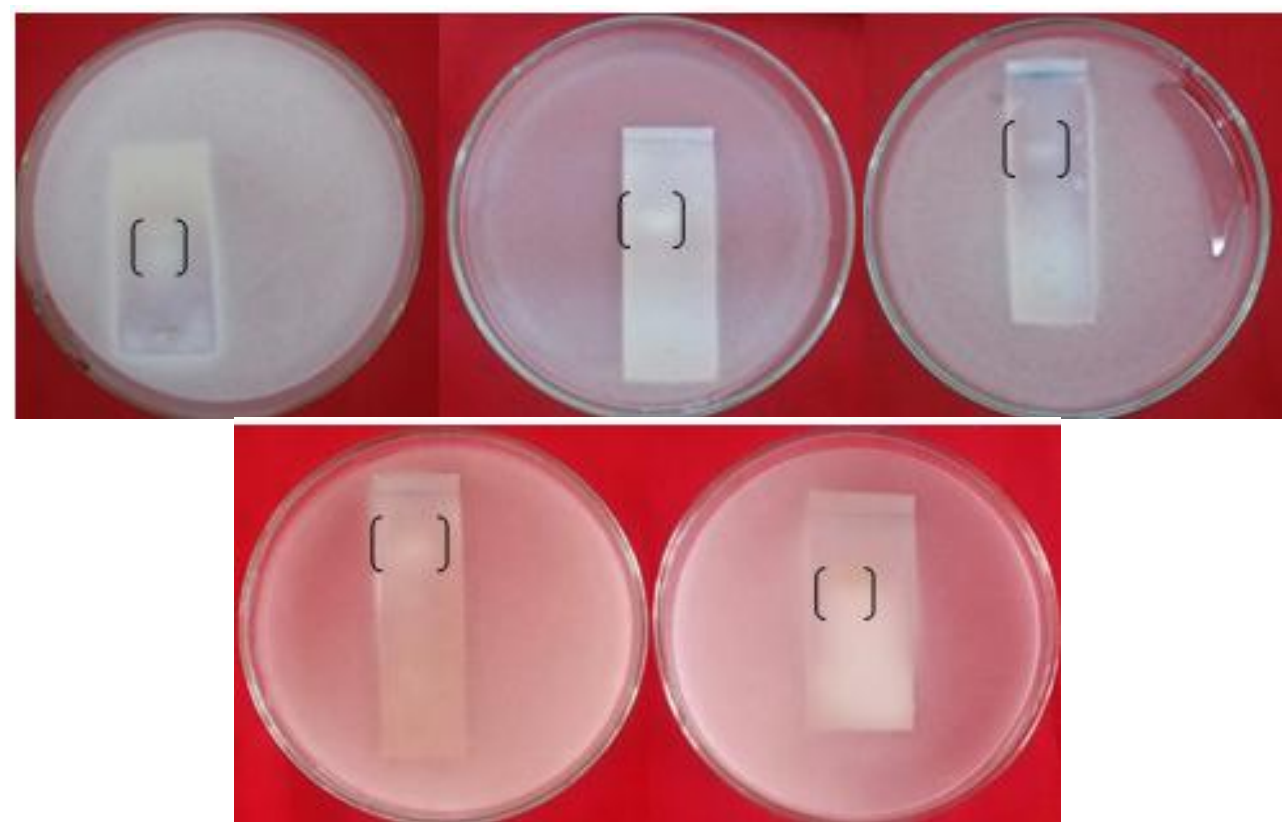

Fig. 1: Results of TLC-bioautography- A. Flavoparmelia caperata [Methanol]; B. Parmotrema grayanum [Ethyl acetate]; C. Parmotrema tinctorum [Ethyl acetate]; D. Physcia aipolia [Ethyl acetate]; E. Teloschistes flavicans [Ethyl acetate].

Table 1: List of lichens collected and identified.

\begin{tabular}{|c|c|c|c|c|c|}
\hline Sl no. & Lichen samples & Family & $\begin{array}{c}\text { Growth } \\
\text { form } \\
\end{array}$ & Spot test & Metabolites in lichens \\
\hline 1 & Flavoparmelia caperata (L.) Ach. & Parmeliaceae & Foliose & $\mathrm{KC}+\mathrm{red}$ & Atranorin, usnic acid, protocetraric acid \\
\hline 2 & Parmotrema austrosinensis (Zahlbr.) Hale & Parmeliaceae & Foliose & $\mathrm{C}+\mathrm{red}, \mathrm{KC}+\mathrm{red}$ & Lecanoric acid \\
\hline 3 & Parmotrema grayanum (Hue) Hale & Parmeliaceae & Foliose & - & Atranorin \\
\hline 4 & Parmotrema reticulatum (Taylor) Choisy & Parmeliaceae & Foliose & $\mathrm{K}+$ yellow, $\mathrm{P}+$ orange & Atranorin, salazinic acid \\
\hline 5 & Parmotrema tinctorum Nyl. & Parmeliaceae & Foliose & $\mathrm{K}+\mathrm{red}, \mathrm{C}+\mathrm{red}$ & Lecanoric acid, atranorin, chloroatranorin \\
\hline 6 & Physcia aipolia (Ehrh. ex Humb.) Furnr. & Physciaceae & Foliose & $\mathrm{K}+$ yellow, $\mathrm{P}+$ yellow & Atranorin, zeorin \\
\hline 7 & Roccella montagnei Bèl. Emend. Awas. & Roccellaceae & Fruticose & $\mathrm{K}+\mathrm{red}, \mathrm{C}+\mathrm{red}$ & Lecanoric acid, erythrin \\
\hline 8 & Teloschistes flavicans (Swartz) Norm. & Teloschistaceae & Fruticose & K+red & Parietin, teloschistin \\
\hline
\end{tabular}


Table 2: Inhibitory activity of lichen extracts against Fusarium solani.

\begin{tabular}{|c|c|c|c|c|c|}
\hline Sl no. & Lichen samples & Solvent extract & Diffusion assay* in mm & $\mathrm{MIC}$ in $\mu \mathrm{g} / \mathrm{ml}$ & Bioautography of $R_{f}$ value \\
\hline \multirow{2}{*}{1} & \multirow{2}{*}{ Flavoparmelia caperata (L.) Ach. } & Ethyl acetate & - & - & - \\
\hline & & Methanol & $12.6 \pm 0.5$ & 1.562 & $0.46,0.6$ \\
\hline \multirow{2}{*}{2} & \multirow{2}{*}{ Parmotrema austrosinensis (Zahlbr.) Hale } & $\overline{\text { Ethyl acetate }}$ & $12.3 \pm 0.5$ & 6.25 & - \\
\hline & & Methanol & - & - & - \\
\hline \multirow{2}{*}{3} & \multirow{2}{*}{ Parmotrema grayanum (Hue) Hale } & Ethyl acetate & $15.3 \pm 0.5$ & 6.25 & 0.64 \\
\hline & & Methanol & - & - & - \\
\hline \multirow{2}{*}{4} & \multirow{2}{*}{ Parmotrema reticulatum (Taylor) Choisy } & $\overline{\text { Ethyl acetate }}$ & $17 \pm 1$ & 6.25 & - \\
\hline & & Methanol & - & - & - \\
\hline \multirow{2}{*}{5} & \multirow{2}{*}{ Parmotrema tinctorum $\mathrm{Nyl}$. } & Ethyl acetate & $18.6 \pm 1.15$ & 1.562 & 0.67 \\
\hline & & Methanol & - & - & - \\
\hline \multirow{2}{*}{6} & \multirow{2}{*}{ Physcia aipolia (Ehrh. ex Humb.) Furnr. } & Ethyl acetate & $14 \pm 1$ & 6.25 & 0.77 \\
\hline & & Methanol & - & - & - \\
\hline \multirow{2}{*}{7} & \multirow{2}{*}{ Roccella montagneiBèl. Emend. Awas. } & Ethyl acetate & $13.3 \pm 0.5$ & 6.25 & - \\
\hline & & Methanol & $11.6 \pm 0.5$ & 6.25 & - \\
\hline \multirow[t]{2}{*}{8} & \multirow{2}{*}{ Teloschistes flavicans (Swartz) Norm. } & Ethyl acetate & $18.6 \pm 0.5$ & 12.25 & 0.61 \\
\hline & & Methanol & - & - & - \\
\hline 9 & Bavistin (positive control) & - & $16 \pm 0$ & 1.562 & - \\
\hline \multirow{2}{*}{10} & \multirow{2}{*}{ Pure Solvent (negative control) } & Methanol & - & - & - \\
\hline & & Ethyl acetate & - & - & - \\
\hline
\end{tabular}

*Values are in mean \pm standard deviation, $n=3$.

Table 3: Total activity of tested lichens.

\begin{tabular}{|c|c|c|c|c|c|}
\hline SI no. & Lichen samples & Solvent extract & MIC in $\mu \mathrm{g} / \mathrm{ml}$ & Mass in $\mathbf{m g}$ & Total activity in $\mathrm{ml}$ \\
\hline \multirow[b]{2}{*}{1} & \multirow{2}{*}{ Flavoparmelia caperata (L.) Ach. } & Ethyl acetate & 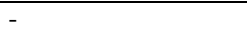 & 700 & 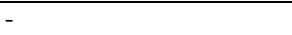 \\
\hline & & Methanol & 1.562 & 1330 & 851.47 \\
\hline \multirow{2}{*}{2} & \multirow{2}{*}{ Parmotrema austrosinensis (Zahlbr.) Hale } & Ethyl acetate & 6.25 & 1270 & 203.2 \\
\hline & & Methanol & - & 700 & - \\
\hline \multirow{2}{*}{3} & \multirow{2}{*}{ Parmotrema grayanum (Hue) Hale } & Ethyl acetate & 6.25 & 440 & 70.04 \\
\hline & & Methanol & - & 590 & - \\
\hline \multirow{2}{*}{4} & \multirow{2}{*}{ Parmotrema reticulatum (Taylor) Choisy } & Ethyl acetate & 6.25 & 520 & 83.2 \\
\hline & & Methanol & - & 492 & - \\
\hline \multirow{2}{*}{5} & \multirow{2}{*}{ Parmotrema tinctorum Nyl. } & Ethyl acetate & 1.562 & 648 & 414.85 \\
\hline & & Methanol & - & 580 & - \\
\hline \multirow{2}{*}{6} & \multirow{2}{*}{ Physcia aipolia (Ehrh. ex Humb.) Furnr. } & Ethyl acetate & 6.25 & 788 & 126.08 \\
\hline & & Methanol & - & 1014 & - \\
\hline \multirow{2}{*}{7} & \multirow{2}{*}{ Roccella montagnei Bèl. Emend. Awas. } & Ethyl acetate & 6.25 & 880 & 140.8 \\
\hline & & Methanol & 6.25 & 1080 & 172.8 \\
\hline \multirow{2}{*}{8} & \multirow{2}{*}{ Teloschistes flavicans (Swartz) Norm. } & Ethyl acetate & 12.25 & 322 & 26.28 \\
\hline & & Methanol & - & 586 & - \\
\hline
\end{tabular}

\section{DISCUSSION}

The results obtained in the present study showed lichens have strong antifungal activity. Evaluation of eight lichen extracts showed to be effective in inhibiting the growth of the fungus. Amongst these, the most promising were Parmotrema tinctorum and Flavoparmelia caperata, which showed highest zone of inhibition in diffusion assay, least MIC value and good inhibition zones against the growth of Fusarium solani due to the fungicidal principle of metabolites present in the lichens. Flavoparmelia caperata had showed lowest MIC of $0.097 \mathrm{mg} / \mathrm{ml}$ when compared to other extracts in inhibiting Fusarium oxysporum sp. Capsici (Shivanna and Garampalli, 2014), whereas moderate activity was reported against Fusarium solani (Babiah et al., 2014b). Antifungal activities of similar results were reported by certain plant extracts to control Fusarium solani in ginger crop (Ramteke and Kamble, 2011). Strong inhibitory effects were observed in Hypogymnia physodes on Fusarium solani (Halama and Haluwin, 2004). Biocontrol potential of a macrolichen Usnea pictoides $\mathrm{G}$. Awasthi were evaluated against Fusarium oxysporum f. sp.
Zingiberi and Pythium aphanidermatum isolated from rhizome rot of ginger (Vinayaka et al., 2014). Heterodermia diademata showed comparative good results against Fusarium solani (Tiwari et al., 2011). The antifungal activity of protolichesterinic acid isolated from Parmelia perlata was tested against plant pathogenic fungus (Goel et al., 2011). Parmotrema andinum was screened against various pathogenic microorganisms in which moderate activity was reported against the pathogen Fusarium solani (Devi et al., 2015). Positive control bavistin showed $16 \pm 0 \mathrm{~mm}$ inhibition zone, which is moderate activity, comparatively tested lichens have showed highest activity and which could be a better performer that the synthetic fungicide. Thippeswamy et al. (2013) also procured the same results where both crude extracts and isolated compounds were more susceptible than Bavistin. In the present result preliminary phytochemical analysis of Parmotrema tinctorum had revealed the presence Tannins, alkaloids, proteins and carbohydrates whereas Flavoparmelia caperata showed most of the constituents like Tannins, Flavanoids, Proteins, Triterpenes, Carbohydrates and Steroids (Rashmi and Rajkumar, 2014). Methanolic extract of Ramalina hossei showed the presence of 
tannins and terpenoids (Kumar et al., 2010). TLC showed lichen metabolites like Atranorin, usnic acid, protocetraric acid in Flavoparmelia caperata, and atranorin, chloroatranorin, lecanoric acid in Parmotrema tinctorum. Santiago et al. (2013) reported usnic acid, norstictic acid, and salazinic acid as bioactive lichen metabolite from Usnea sp. by TLC- bioautography against pathogens.

The results of Bioautography showed good results in most of the samples tested, which will be useful in the further isolation and characterization of metabolites.

\section{CONCLUSION}

The present work concentrated on finding out the effect of natural products, which are eco-friendly and less harmful than commercial synthetic compounds like fungicides. Consequently the investigated lichens could be used as a natural fungicide in the management of the diseases caused by plant pathogens. Further studies on the fractionation of solvent extracts and characterization may reveal the compounds responsible for the antifungal potentials.

\section{ACKNOWLEDGEMENTS}

One of the author (Rashmi S.) is thankful to the University of Mysore for awarding NON-NET fellowship during preparation of this article.

\section{REFERENCES}

Aberkene A, Cuenca-Estrella M, Gomez-Lopez A, Petrikkou E, Mellado E, Monzon A, Rodriguez-Tudela JL, the Eurofung Network. Comparative evaluation of two different methods of inoculum preparation for antifungal susceptibility testing of filamentous fungi. J. Antim. Chem. 2002; 50:719-722.

Agrios GN. 2005. Plant pathology, 5th edition. Elsevier Academic Press, U.S.A.

Andrews JN. Determination of Minimum inhibitory concentrations. Journal of Antimicrobial chemotherapy. 2001; 48:5-16.

Awasthi DD. 1988. A key to the macrolichens of India and Nepal, J Hattori Bot Lab. 65:207-302.

Awasthi DD. 2000. A hand book of lichens.Bishen Singh Mahendra Pal Singh. India.

Babiah PS, Upreti DK, John SA. An in vitro analysis of antifungal potential of lichen species Parmotrema reticulatum against phytopathogenic fungi. Int J Curr Microbiol App Sci. 2014a; 3 (12):511518.

Babiah PS, Upreti DK, John SA. Fungicidal Efficacy of a Foliose Lichen Flavoparmelia caperata (L.) Hale against Phytopathogenic Fungi. Int J Curr Res Biosci Plant Biol. 2014b; 1 (5):38-44.

Boustie J. Grube M. Lichens-a promising source of bioactive secondary metabolites. Plant Genet Resour. 2005; 3 (2):273-287.

Culberson CF. Improved conditions and new data for the identification of lichen products by a standardized Thin Layer Chromatographic method. Journal of Chromatography. 1972; 72:113-125.

Daike GN, Euison S. Association of pathogens with rhizome rot of ginger in Kerala. Indian Phytopath. 1989; 42 (1):116-119.

Devi AB, Mohabe S, Reddy MA, Nayaka S. Efficacy of a potential lichen Parmotrema andinum (Müll. Arg.) Hale against pathogenic microorganisms. Journal on New Biological Reports. 2015; 4 (2) $149-156$.
Dohroo NP. ICAR report on multi location project on rhizome rot of ginger. Dr YS Parmar University of Horticulture and Forestry, Nauni- solan. 1993; 4 (4): 38.

Domsch KH, Gams, W. 1972. Fungi in agricultural soils.T. \& A. Constable Ltd., Edinburgh.

Eloff JN. A sensitive and quick Microplate method to determine the Minimal inhibitory concentration of Plant extracts of Bacteria.PlantaMedica. 1998; 64:711-713.

Goel M, Sharma PK, Dureja P, Rani A, Uniyal PL. Antifungal activity of extracts of the lichens Parmelia reticulata, Ramalina roesleri, Usnea longissima and Stereocaulon himalayense. Archives of Phytopathology and Plant Protection. 2004; 44 (13):1300-1311.

Goel M, Dureja P, Rani A, Uniyal PL, Laatsch H.Isolation, Characterization and Antifungal Activity of Major Constituents of the Himalayan Lichen Parmelia reticulata Tayl. J. Agric. Food Chem. 2011; 59: 2299-2307.

Goward T, McCune B and Meidinger D. 1994. The Lichens of British Columbia, Illustrated Keys: Part 1-Foliose and Squamulose Species. Ministry of Forests Research Program.

Halama P,Haluwin CV. Antifungal activity of lichen extracts and lichenic acids. BioControl. 2004; 49: 95-107.

Hale ME. 1983. The biology of lichens, 3rd edition. EdwardArnold. London.

Huneck S. The significance of lichens and their metabolites. Naturwissenschaften. 1999; 86: 559-570.

Kekuda PTR, Vivek MN, Kambar Y,Manasa, M. Biocontrol potential of Parmotrema species against Colletotricum capsici isolated from anthracnose of Chilli. Journal of Biological \& scientific opinion, 2014; 2 (2):166-169.

Kumar SNS. Ginger rot by Fusarium solani. Journal of Plant crops. $1977 ; 5: 122$.

Malcolm WM, Galloway DJ. 1997. The New Zealand lichens: Checklist, Key, and Glossary. Museum of New Zealand Te Papa Tongarewa Wellington.

Mdee LK, Masoko P, Eloff JN. The activity of extracts of seven common invasive plant species on fungal phytopathogens. South African Journal of Botany. 2009; 75(2): 375-379.

Molnár K, Farkas E. Current results on biological activities of lichen secondary metabolites: a review. ZeitschriftfürNaturforschung. 2010; 65C: 157-173.

Muller K. Pharmaceutically relevant metabolites from lichens. Applied Microbiology and Biotechnology. 2002;56:9-16.

Praveen Kumar SV, Prashith Kekuda TR, Vinayaka KS,Swathi D, Mallikarjun N,Nishanth BC. Studies on Proximate Composition, Antifungal andAnthelmintic activity of a macrolichenRamalina hossei $\mathrm{H}$. Magn\& G. Awasthi. International Journal of Biotechnology and Biochemistry. 2010; 6 (2): 193-203.

Ramteke PK, Kamble SS. Evaluation of phytoextracts against Fusarium solani (Mart.) Sacc. causing rhizome rot of ginger (Zingiber officinale Rosc.). Current biotica. 2011; 4 (4):469-474.

Rankovic B, Misic M, Sukdolak S. The antimicrobial activity of substances derived from the lichens Physcia aipolia, Umbilicaria polyphylla, Parmelia caperata and Hypogymnia physodes. World journal of microbiology and biotechnology. 2008; 24:1239-1242.

Rankovic' B, Mis 'ic' M, Sukdolak S. The antimicrobial activity of substances derived from the lichens Physcia aipolia, Umbilicaria polyphylla, Parmelia caperata and Hypogymnia physodes. World J Microbiol Biotechnol. 2008; 24:1239-1242.

Rashmi S,Rajkumar HG. Preliminary phytochemical screening of different solvent extracts of lichens from Kodagu district, Karnataka. Journal of Pharmacognosy and Phytochemistry. 2014;3 (4):209-212.

Shivanna R, Garampalli RH. Efficacy of lichen extracts as biocontrol agents against Fusarium oxysporumF. Sp. capsici. Advances in Applied Science Research. 2014; 5 (5):273-277.

Santiago KAA, Sangvichien E, Boonpragob K, dela Cruz TEE. 2013-Secondary metabolic profiling and antibacterial activities of different species of Usnea collected in Northern Philippines. Mycosphere. 2013; 4 (2), 267-280. 
Tarafdar J, Saha N. Correlation study on population dynamics of ginger soft rot inciting pathogens under different organic amendments, disease incidence and its survival in Darjeeling hill soils. Proceedings of the $13^{\text {th }}$ ISTRC Symposium. 2007; 165-169.

Thippeswamy B, Sushma NR, Naveenkumar KJ. Evaluation of antimicrobial property of lichen- Parmelia perlata. African Journal of Pharmacy andPharmacology. 2013; 7 (20): 1242-1250.

Tiwari P, Rai H, Upreti DK, Trivedi S, Shukla P. Assessment of Antifungal Activity of Some Himalayan Foliose Lichens against Plant Pathogenic Fungi. American Journal of Plant Sciences. 2011; 2:841-846.

Vinayaka KS, Kekuda PTR, Nawaz NAS, Junaid S, Dileep N, Rakesh KN. Inhibitory activity of Usnea pictoidesg. Awasthi (Parmeliaceae) against Fusarium oxysporumf.sp. zingiberi and Pythium aphanidermatum isolated from rhizome rot of Ginger. Life sciences Leaflets. 2014; 49:17-22.
Vivek MN, Manasa M, Kambar Y,KekudaPTR, Raghavendra HL. 2014. Antifungal efficacy of three bioactive Parmotrema species from Western Ghats of Karnataka, India. International Journal of Agriculture and Crop Sciences. 2014; 7 (12): 968-973.

\section{How to cite this article:}

Rashmi Shivanna, Rajkumar H Garampalli. Evaluation of fungistatic potential of lichen extracts against Fusarium solani (Mart.) Sacc. causing Rhizome rot disease in Ginger. J App Pharm Sci, 2015; 5 (10): 067-072. 